\title{
Physiological response of cidró to different water replacement levels in two seasons of the year
}

\author{
Denise Schmidt ${ }^{1}$; Braulio O Caron ${ }^{1}$; Luciano Schwerz ${ }^{1}$; Paulo A Manfron ${ }^{2}$; Elvis F Elli ${ }^{1}$; Felipe Schwerz ${ }^{1}$ \\ ${ }^{1}$ Universidade Federal de Santa Maria (UFSM), Frederico Westphalen-RS, Brasil; denise@ufsm.br; otomarcaron@yahoo.com.br; \\ lucianosch@emater.tche.br; elvisfelipeelli@yahoo.com; felipe_schwerz@hotmail.com (autor para correspondência); ${ }^{2}$ Universidade \\ Federal de Santa Maria (UFSM), Santa Maria-RS, Brasil; pamanfron@hotmail.com
}

\begin{abstract}
We aimed to determine the response of cidró (Aloysia triphylla) submitted to different water replacement levels in summer and winter, in order to understand and relate the plant physiological performance under adverse weather conditions. The research was developed in a protected environment, in the city of Frederico Westphalen, Rio Grande do Sul State, Brazil. The experimental design was completely randomized, arranged in a $2 \times 4 \times 2$ factorial scheme, two seasons of the year (summer and winter), four water availability $(50,75,100$, $125 \%$ of ETo) and two faces of leaf (abaxial and adaxial), with four replications. There were evaluated stomatal vapor diffusion resistance $(\mathrm{s} / \mathrm{cm})$, transpiration $\left(\mu \mathrm{g} / \mathrm{cm}^{2} / \mathrm{s}\right)$ and leaf temperature $\left({ }^{\circ} \mathrm{C}\right)$, on both faces of the leaf from 10 a.m. to 11 a.m., 1 p.m. to 2 p.m. and 4 p.m. to 5 p.m., 45 days after the beginning of the season. We concluded that the physiological response of cidró plants was influenced by water replacement levels, in a different way according to the seasons of the year. The summer season was responsible for the highest values of incident photosynthetically active radiation, leaf temperature, transpiration and stomatal vapor diffusion resistance. The reduction in water availability promoted the increase in values for stomatal resistance to vapor flow, reducing leaf transpiration rate. The incident photosynthetically active radiation, leaf temperature and transpiration showed highest values on the abaxial face of the studied species.
\end{abstract}

Keywords: Aloysia triphylla, weather conditions, stomatal resistance, leaf temperature, transpiration.

\section{RESUMO}

Resposta fisiológica do cidró a diferentes níveis de reposição hídrica em duas estações do ano

Com o propósito de compreender e relacionar o desempenho fisiológico das plantas às adversidades meteorológicas, objetivou-se determinar a resposta fisiológica de plantas de cidró (Aloysia triphylla) submetidas a diferentes níveis de reposição hídrica no verão e inverno. $\mathrm{O}$ trabalho foi desenvolvido em ambiente protegido, no município de Frederico Westphalen-RS. O delineamento utilizado foi blocos completos ao acaso em um esquema fatorial $2 \times 4 \times 2$, sendo duas estações do ano (verão e inverno), quatro disponibilidades hídricas $(50,75,100,125 \%$ da ETo) e duas faces da folha (abaxial e adaxial), com quatro repetições. Avaliou-se a resistência à difusão de vapor pelos estômatos $(\mathrm{s} / \mathrm{cm})$, transpiração $\left(\mu \mathrm{g} / \mathrm{cm}^{2} / \mathrm{s}\right)$ e a temperatura da folha $\left({ }^{\circ} \mathrm{C}\right)$, em ambas as faces da folha, no período compreendido entre 10 às 11,13 às 14 e 16 às 17 horas, aos 45 dias após o início da estação. A resposta fisiológica das plantas de cidró foi influenciada pelo nível de reposição hídrica, de forma diferenciada entre as estações do ano. A estação do verão foi responsável pelos maiores valores de radiação fotossinteticamente ativa incidente, temperatura da folha, transpiração e resistência à difusão de vapor pelos estômatos. A redução na disponibilidade hídrica promoveu o aumento nos valores de resistência estomática ao fluxo de vapor, reduzindo a taxa de transpiração das folhas. A radiação fotossinteticamente ativa incidente, temperatura da folha e transpiração apresentaram maiores valores na face abaxial da espécie estudada.

Palavras-chave: Aloysia triphylla, condições meteorológicas, resistência estomática, temperatura da folha, transpiração.

\section{Received on October 23, 2015; accepted on September 26, 2016}

$T^{1}$ he medicinal species Aloysia triphylla (Verbenaceae), botanical synonym Lippia citriodora, popularly known as "cidró", "cidrão", herb Luisa, among others, is a native species in South America. This herb is composed of high contents of volatile oils that present astringent and aromatic properties, also act as mild sedatives (Paulus et $a l ., 2013)$. The economic interest in this species is mainly due to the commercial exploitation of the essential oil from the leaves of the plant, which has a high market value for its use in several industrial sectors, with emphasis on the pharmaceutical and perfumery industries (Calzada et al., 2010).

The active ingredients (a.i) may vary due to meteorological conditions, like air temperature, solar radiation, humidity, atmospheric vapor pressure deficit and water availability (Rodrigues-das-Dores \& Casali, 2007), as well as technical aspects of cultivation, in order to obtain the highest content of chemical compounds for each species.

The adaptation of a species to a certain environmental condition is related to, among other factors, energy balance, which is governed by stomatal 
opening and closing (Taiz \& Zeiger, 2013). This process is related both to light intensity and the water content found in the leaves of the plants. Thus, the stomatal frequency and the photosynthetic apparatus directly influence plant production and biomass constitution (Costa \& Marenco, 2007).

Plant physiological activity may alter in response to adverse weather conditions, as is the case of water and thermal stresses. Water stress, characterized by reduction or excess of water, can damage a specific organ or the entire plant. During a long period of water deficit, plants close their stomata reducing the intensity of gas exchange, reducing dissipation of thermal energy and, consequently, phytomass accumulation and leaf expansion rate, accelerating leaf senescence process (Taiz \& Zeiger, 2013).

Transpiration rate of plants reflects their need for water. Thus, transpiration values lower than plant physiological need cause water deficit, reducing the growth and development of plants (Casaroli et al., 2008). Moreover, Caron et al. (2014) report that the intensity of incident photosynthetically active radiation modifies the physiological behavior (transpiration and stomatal resistance), which causes variation on plant metabolic activity.

Some studies have been carried out aiming to evaluate biomass production and the oil content of cidró (Brant et al., 2008, 2010; Paulus et al., 2013), since this species has aroused economic interest, considering exploitation of compounds with therapeutic properties. Research related to ecophysiology of this species are scarce. Thus, this work aimed to determine physiological responses of cidró plants, submitted to different levels of water replacement in summer and winter, in order to understand and relate the plant physiological performance under adverse weather conditions.

\section{MATERIAL AND METHODS}

The work was carried out in a protected environment, in the city of Frederico Westphalen, Rio Grande do Sul, Brazil (27023'48”'S; 53025'45”'W, altitude $181 \mathrm{~m}$ ). The soil of the experimental area was classified as typic alumino-ferric Red Latossol (Embrapa, 2006), with sand, silt and clay contents, $23.2 \% ; 28.5 \%$ and $48.3 \%$, respectively. Soil chemical composition was obtained through laboratory analysis, being: $\mathrm{pH}$ in water $=5.7 ; \mathrm{P}($ Mehlich $)=5.0$ $\mathrm{mg} / \mathrm{dm}^{3} ; \mathrm{K}=128.5 \mathrm{mg} / \mathrm{dm}^{3} ; \mathrm{Ca}=12.5$ $\mathrm{cmol}_{\mathrm{c}} / \mathrm{dm}^{3} ; \mathrm{Mg}=4.8 \mathrm{cmol}_{\mathrm{c}} / \mathrm{dm}^{3} ; \mathrm{Al}=0.0$ $\mathrm{cmol} / \mathrm{dm}^{3} ; \mathrm{CTC}=20.9 \mathrm{cmol} / \mathrm{dm}^{3}$; base saturation $=84.2 \%$ and organic matter $=3.9 \%$. According to Köppen weather classification, the local climate is Cfa type, humid subtropical climate with average annual temperature of $19.1^{\circ} \mathrm{C}$, ranging from maximum of $38^{\circ} \mathrm{C}$ and minimum of $0^{\circ} \mathrm{C}$.

An arch-type greenhouse was used, $3.5 \mathrm{~m}$ ceiling height and dimensions of $10 \mathrm{~m}$ wide and $20 \mathrm{~m}$ long. The structure was covered with $150 \mu \mathrm{m}$ thick polyethylene film. Management of the curtains was carried out daily with the purpose of favoring the ventilation, reducing the temperature amplitude in summer, when temperatures are higher, and to avoid circulation of strong winds and the entrance of cold air, as well as rainwater in winter.

The experimental design was completely randomized, arranged in a $2 \times 4 \times 2$ factorial scheme, two seasons of the year (summer and winter), four water availability $(50,75,100,125 \%$ of ETo) and two faces of leaf (abaxial and adaxial), with four replications. The authors used the Penman-Monteith method, according to FAO irrigation and drainage paper No. 56 (Allen et al., 1998), in order to determine the four levels of water availability, $50,75,100,125 \%$ of ETo reference evapotranspiration $(\mathrm{mm} /$ day) for the external environment.

Meteorological variables for the calculation of ETo were temperature and relative humidity, rainfall, global radiation and wind speed, obtained daily at automatic weather station (INMET), located approximately 300 meters from the experiment.

Experimental units were composed of two cidró plants, spacing $0.8 \mathrm{~m}$ between plants and $1 \mathrm{~m}$ between lines, surrounded by two border lines. Seedlings were produced in tubes with commercial substrate, from a matrix located in the medicinal vegetable garden of Federal University of Santa Maria, campus Frederico Westphalen, using cuttings, with stakes of $25 \mathrm{~cm}$ length. The authors applied indole-butyric acid on the stakes, in the concentration of $1000 \mathrm{ppm}$, aiming faster rooting. After rooting, 66 days after cutting, seedlings were transplanted to the greenhouse, on November 3, 2011. The water replacement was carried out through irrigation with the aid of a sprinkler and with irrigation shift fixed every two days. Total levels of water replacement of each cycle and daily can be observed in Table 1.

The traits evaluated were diffusive resistance $(\mathrm{DR}, \mathrm{s} / \mathrm{cm})$, transpiration $(\mathrm{E}$, $\left.\mu \mathrm{g} / \mathrm{cm}^{2} / \mathrm{s}\right)$ and leaf temperature $\left(\mathrm{T}_{\text {lef }},{ }^{\circ} \mathrm{C}\right)$. Evaluations related to water vapor exchange were carried out from 10 to 11 a.m., from 1 to 2 p.m. and from 4 to 5 p.m., at 92 and 288 days after transplanting (DAT), using two fully expanded leaves, located in the upper third of the main stem, according to the methodology described by Martinez \& Moreno (1992).

Analyses were carried out with the aid of a dynamic balance porometer model LI-COR 1600, being the readings taken on both faces of the leaf, abaxial (inferior) and adaxial (superior), measuring the contribution of each face of the leaf in plant gas exchanges. At the same time, the authors monitored incident photosynthetically active radiation (PAR, $\mu \mathrm{mol} / \mathrm{s} / \mathrm{m}^{2}$ ), using a quantum sensor coupled to the apparatus.

Evaluations were carried out on the day that marked the half of each station studied, it means, on February 5, 2012 and August 6, 2012, for summer and winter, respectively, considered typical days in agroclimatology. These days were chosen, among others in the mentioned seasons, since they show the celestial vault in conditions of zero cloudiness, allowing this way, to obtain the maximum effects of weather elements on the cultivation environment and, consequently on evaluated traits, in order to achieve the objectives of the work. This same methodology was used by Caron et al. (2014) when determining 
physiological relations in seedlings of Bauhinia forficata (pata de vaca).

Data obtained were subjected to analysis of variance at 5\% probability, using software "Statistical Analysis System” (SAS, 2003). Significant variables related to water availability (quantitative) were evaluated using polynomial regression, whereas qualitative variables (face of the leaf and seasons of the year) were compared using the Tukey test, at 5\% probability.

\section{RESULTS AND DISCUSSION}

The authors verified significant effect for all variables evaluated in relation to the season of the year and water availability. On the other hand, evaluating the face of the leaf, the authors observed significance for transpiration and stomatal vapor diffusion resistance, as well as a triple interaction among these factors.

The increase of water availability allowed an increasing transpiration behavior, whereas leaf temperature and stomatal vapor diffusion resistance showed reverse response (Figure 1). These responses are due to summer being characterized by the hotter days (air temperatures), the higher incidence of solar radiation and lower relative humidity, presenting higher atmospheric evaporative demand.

Thus, the authors concludes that the variables studied showed, in average, superior values during summer, leaf temperature $9.8^{\circ} \mathrm{C}$, transpiration $4.1 \mu \mathrm{g}$ / $\mathrm{cm}^{2} / \mathrm{s}$, stomatal vapor diffusion resistance $0.66 \mathrm{~s} / \mathrm{cm}$ and photosynthetically active radiation $196.9 \mu \mathrm{mol} / \mathrm{s} / \mathrm{m}^{2}$, superior values than the observed in winter.

In relation to transpiration and stomatal resistance, the authors observed inverse relation between the two variables: lower stomatal resistance and higher transpiration. The authors also verified that the plants that were submitted to water stress showed lower leaf water potential, occurring higher stomatal resistance and, consequently, lower transpiration. These physiological responses result indirectly, in soil water conservation, for maintaining their biochemical and structural characteristics, in order to survive under the conditions mentioned.

Similar results were found by Ciavatta (2010), studying the effect of fertigation on eucalyptus genotypes. These authors observed that plants grown during summer showed higher transpiration values. Nogueira et al. (2000) verified significant increases in water demand in acerola due to increase of the transpiration rate in the season of higher temperature, lower relative humidity and lower rainfall.

As water availability increases, leaf temperature decreases, being the most pronounced response in summer (Figure 1A). Favorable water conditions contribute to transpiration process and, consequently, in latent heat loss, allowing the plants to control their temperature (Nascimento et al., 2011). Oliveira et al. (2005) analyzing stomatal conductance in bean crop, concluded that the leaf temperature in lower water availability treatments was higher than the others.

A decrease in water availability resulted in a decrease of transpiration rate in winter and in the abaxial face of the leaf (Figure 1C and 2C), as observed by Nogueira et al. (2001) in acerola, observing reductions in this physiological variable due to a longer period of water deficit.

Stomatal vapor diffusion resistance showed higher values in lower water availability, in winter and in the abaxial face of the leaf (Figure 1D and 2D). During a period of water deficit, the plants mobilize their large variety of defense mechanisms, such as closing their stomata, which rapidly close as temperature rises. Thereat, plant physiological performance is affected, mainly in relation to transpiration rate and stomatal opening and closing,

Table 1. Total levels of water replacement of each cycle and daily ( $\mathrm{mm} /$ day), in the respective water availability during the two seasons of the year. Frederico Westphalen, UFSM, 2012.

\begin{tabular}{|c|c|c|c|c|c|}
\hline \multirow{2}{*}{ Season } & & \multicolumn{4}{|c|}{ Water availability (\% ETo) } \\
\hline & & 125 & 100 & 75 & 50 \\
\hline \multirow{2}{*}{ Summer } & Total & 550.32 & 448.25 & 346.19 & 244.13 \\
\hline & $\mathrm{mm} /$ day & 7.56 & 6.16 & 4.76 & 3.35 \\
\hline \multirow{2}{*}{ Winter } & Total & 235.80 & 188.64 & 141.48 & 94.32 \\
\hline & $\mathrm{mm} /$ day & 3.24 & 2.59 & 1.94 & 1.30 \\
\hline
\end{tabular}

Table 2. Unfolding of inter-season interaction, availability of water and face of the leaf, for physiological variables: transpiration and vapor diffusion resistance in cidró. Frederico Westphalen, UFSM, 2012.

\begin{tabular}{|c|c|c|c|c|c|}
\hline \multirow{2}{*}{ Season } & \multirow{2}{*}{ Face } & \multicolumn{4}{|c|}{ Water availability (\% ETo) } \\
\hline & & 125 & 100 & 75 & 50 \\
\hline & & \multicolumn{4}{|c|}{ Transpiration $\left(\mu \mathrm{g} / \mathrm{cm}^{2} \mathrm{~s}\right)$} \\
\hline \multirow{2}{*}{ Summer } & Abaxial & $13.46 \mathrm{aA}$ & $14.03 \mathrm{aA}$ & $13.61 \mathrm{aA}$ & $11.41 \mathrm{aA}$ \\
\hline & Adaxial & $9.84 \mathrm{aB}$ & $11.34 \mathrm{aB}$ & $5.67 \mathrm{aB}$ & $7.53 \mathrm{aB}$ \\
\hline \multirow{2}{*}{ Winter } & Abaxial & $10.31 \mathrm{bA}$ & $8.63 \mathrm{bA}$ & $6.56 \mathrm{bA}$ & $4.94 \mathrm{bA}$ \\
\hline & Adaxial & $8.42 \mathrm{bB}$ & $6.52 \mathrm{bB}$ & $4.78 \mathrm{bB}$ & $4.31 \mathrm{bA}$ \\
\hline & & \multicolumn{4}{|c|}{ Vapor diffusion resistance $(\mathrm{s} / \mathrm{cm})$} \\
\hline \multirow{2}{*}{ Summer } & Abaxial & $2.45 \mathrm{aB}$ & $3.05 \mathrm{aB}$ & $3.05 \mathrm{aB}$ & $3.57 \mathrm{bB}$ \\
\hline & Adaxial & $4.07 \mathrm{aA}$ & $4.35 \mathrm{aA}$ & $6.59 \mathrm{aA}$ & $5.50 \mathrm{aA}$ \\
\hline \multirow{2}{*}{ Winter } & Abaxial & $1.83 \mathrm{bB}$ & $2.17 \mathrm{bB}$ & $3.47 \mathrm{aB}$ & $4.30 \mathrm{aB}$ \\
\hline & Adaxial & $2.74 \mathrm{bA}$ & $3.21 \mathrm{bA}$ & $4.53 \mathrm{bA}$ & $5.11 \mathrm{aA}$ \\
\hline
\end{tabular}

Means followed by the same letter in the column (lowercase between season of the year and uppercase letter between the face of the leaf) differ by Tukey test at $5 \%$ error probability. 


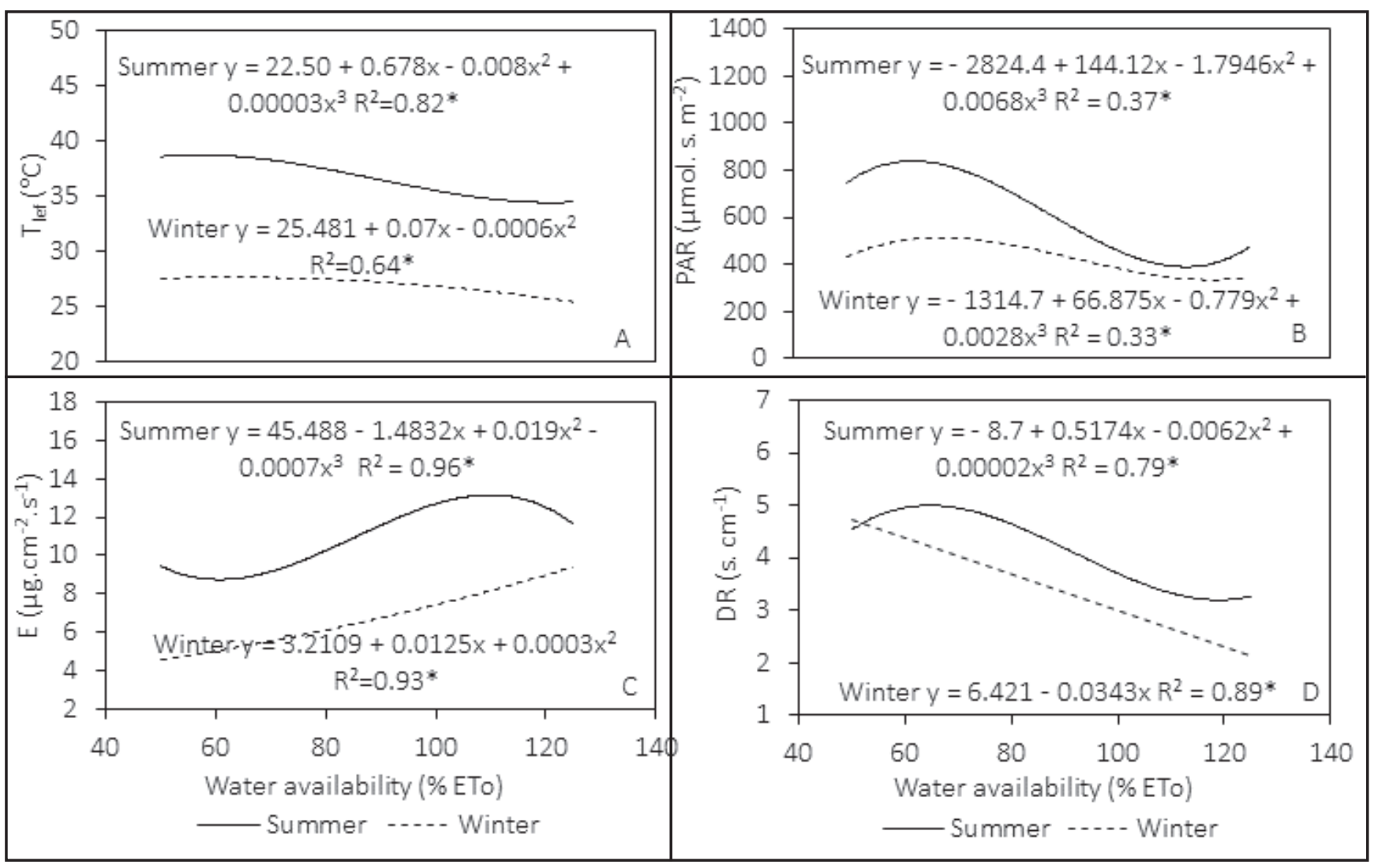

Figure 1. Leaf temperature (A), photosynthetic active radiation (B), transpiration (C) and vapor diffusion resistance (D) in plants of cidró evaluated in the summer and winter related to water availability (\%ETo) based on the reference evapotranspiration ETo (mm/day) . Frederico Westphalen, UFSM, 2012.

producing changes in production and translocation of assimilates, which influences the plant growth rate. According to Silva \& Casali (2000), low water availability can influence several physiological and metabolic processes in plant, such as stomatal closing, a decrease in growth rate, accumulation of solutes and antioxidant and expression of stress-related genes.

Oliveira et al. (2005), studying effects of water deficit on stomatal behavior and leaf temperature in beans, concluded that plants under water deficit conditions show higher values for stomatal resistance and leaf temperature. Mendes et al. (2007), evaluating cowpea cultivars submitted to water deficit in vegetative and reproductive phases, found significant reductions in leaf water potential, stomatal conductance and leaf transpiration, with an increase of the leaf temperature.

Transpiration was higher in all levels of water availability during summer; the abaxial face was responsible for the highest values observed in both seasons, except for availability of $50 \%$, which does not show statistical difference (Table 2). Thus, the abaxial face of cidró leaves was responsible for 57.8 ; $55.3 ; 70.6$ and $60.2 \%$ of transpiration in summer and 55; $57 ; 58$ and $53 \%$ of transpiration in winter, in water availability of $125,100,75$ and $50 \%$ of ETo, respectively.

Thus, the authors pointed out the importance of the abaxial face in physiological activity of cidró leaves, probably due to the higher number of stomata, since it shows the best contribution to plant transpiration rate. The higher number of stomata on the abaxial face can result in water loss reduction by transpiration, due to indirect incidence solar radiation, compared to the adaxial face.

Elli et al. (2013), analyzing the physiological behavior in pitangueira seedlings, concluded that the adaxial face of the leaf tends to show higher transpiration values, probably due to the higher stomata number. In this context, Martins \& Floriano (2002), studying the leaf anatomy of Illicium verum (Illiciaceae), analyzed that the quantity of stomata per area $\left(\mathrm{mm}^{2}\right)$ differed between adaxial and abaxial surfaces of the leaf, considering that the inferior face showed higher number, and that it could have influenced lower diffusive resistance and higher transpiration rate.

When comparing transpiration in the two seasons of the year, the authors observed a demand in the order of $5 ; 13 ; 13$ and $17 \%$ superior in summer in water availability 125 , 100,75 and $50 \%$ of ETo, respectively (Table 2). Transpiration is directly related to the environmental conditions where the plant grows. So, the highest photosynthetically active radiation (Figure 1B) resulted in rising air and leaf temperatures and, consequently, in atmospheric vapor pressure deficit, causing higher water demand and, consequently, higher transpiration rate in summer. 


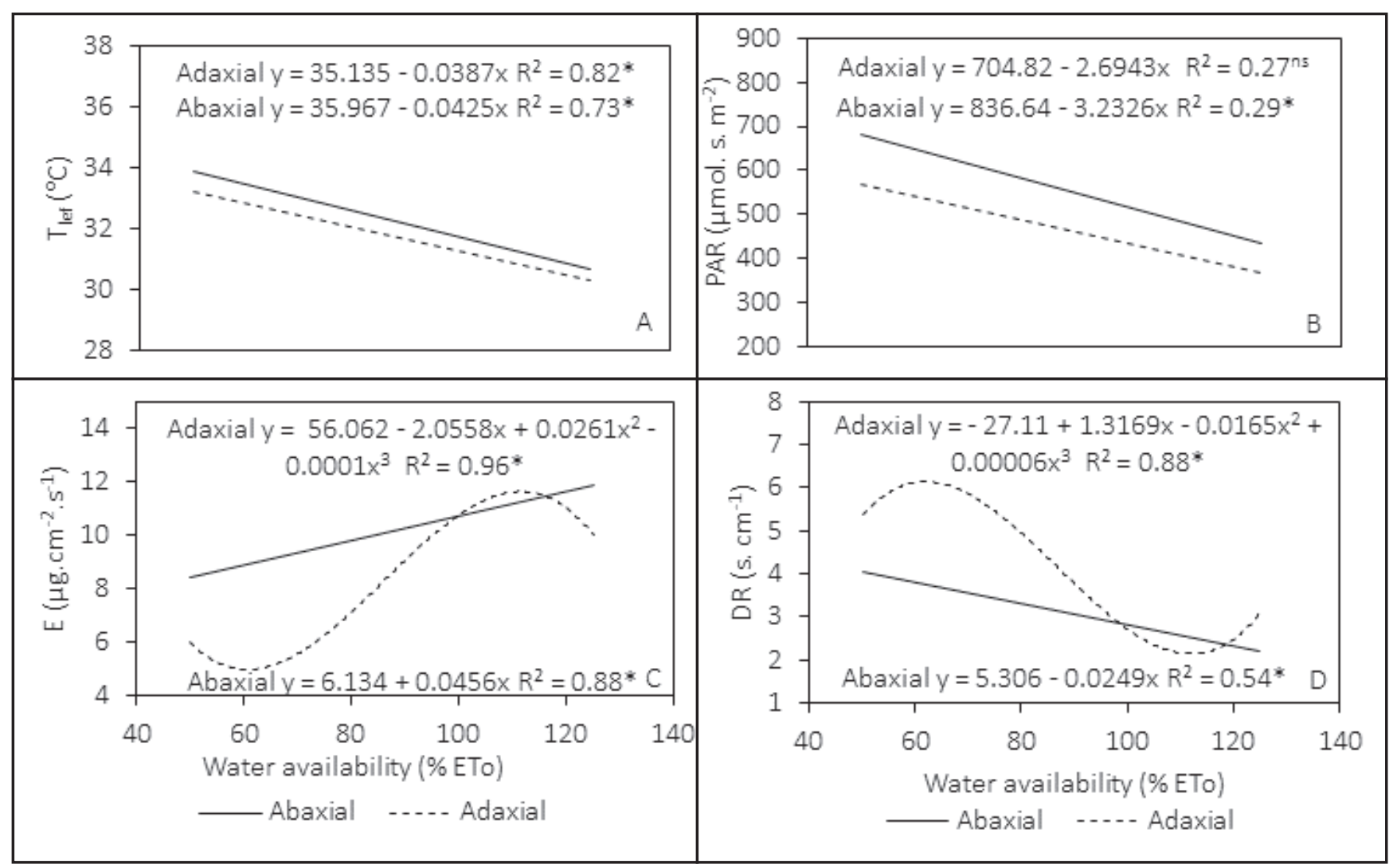

Figure 2. Leaf temperature (A), photosynthetic active radiation (B), transpiration (C) and vapor diffusion resistance (D) evaluated on the abaxial and adaxial face of cidró leaves, related to water availability (\%ETo) based on the reference evapotranspiration ETo (mm/day) . Frederico Westphalen, UFSM, 2012.

Transpiration is controlled by stomatal resistance to vapor diffusion, thus, the values that were observed became the inverse, it means, the abaxial face responsible for the highest transpiration showed lowest values for DR, 25; $17.6 ; 37$ and $21.3 \%$ in summer and $20 ; 19.3 ; 13.2$ and $8.6 \%$ in winter for water availability 125, 100, 75 and $50 \%$ of ETo, respectively.

The soil water availability affects directly transpiration rate, stomatal conductance and photosynthesis (Schippers et al., 2015), since stomatal opening and closing are controlled by soil water potential. Absence of water stress allows internal concentration of $\mathrm{CO}_{2}$ in the leaves due to higher stomatal conductance, increasing photosynthetic rate in plants (Van der Sleen et al., 2014).

Studies have been reporting the dependence of water demand in relation to the incidence of solar radiation in the environment (Dalmago et al., 2006; Pivetta et al., 2010), since it is responsible for environmental heating processes, biomass accumulation by photosynthesis, control of stomatal opening among others. Photosynthesis is strongly related to the availability of photosynthetically active radiation, and a non-linear increase of photosynthesis in relation to higher radiation availability is observed (Mercado et al., 2009). However, even if all the processes that trigger the gas exchange occur, in the presence of reduced water availability, the plant mobilizes mechanisms to reduce transpiration. In this work, this process was through an increased resistance to vapor flow through stomata.

When analyzing transpiration rate on the faces of the leaf, the authors reported that, in winter, both abaxial and adaxial faces show similar behavior and an increasing response due to the increase of water replacement levels. The abaxial face was responsible for the most of leaf transpiration surpassing the adaxial face in $0.99 \mu \mathrm{g} / \mathrm{cm}^{2} / \mathrm{s}$.

Also in winter, a tendency for decreasing quadratic response to water availability, for both faces of the leaf in relation to vapor diffusion resistance, was observed (Figure 3). In studies carried out by Guimarães et al. (2006), when evaluating stomatal diffusive resistance of adaxial and abaxial faces of the leaf of beans, under water deficit conditions, these authors found similar values among genotypes, on both faces of the leaves during winter.

In summer, adaxial face of cidró leaves showed wide variation in transpiration and in vapor diffusion resistance, being more pronounced in $100 \%$ of ETo (figure 3B). This result can be related to gas exchange balance, whereas transpiration increases, stomatal resistance decreases with an increase in water availability. According to Batista et al. (2010), in summer, incidence solar radiation is higher on adaxial face of the leaves providing, this way, higher variations on this face comparing to the abaxial one.

The results found in this study allow 


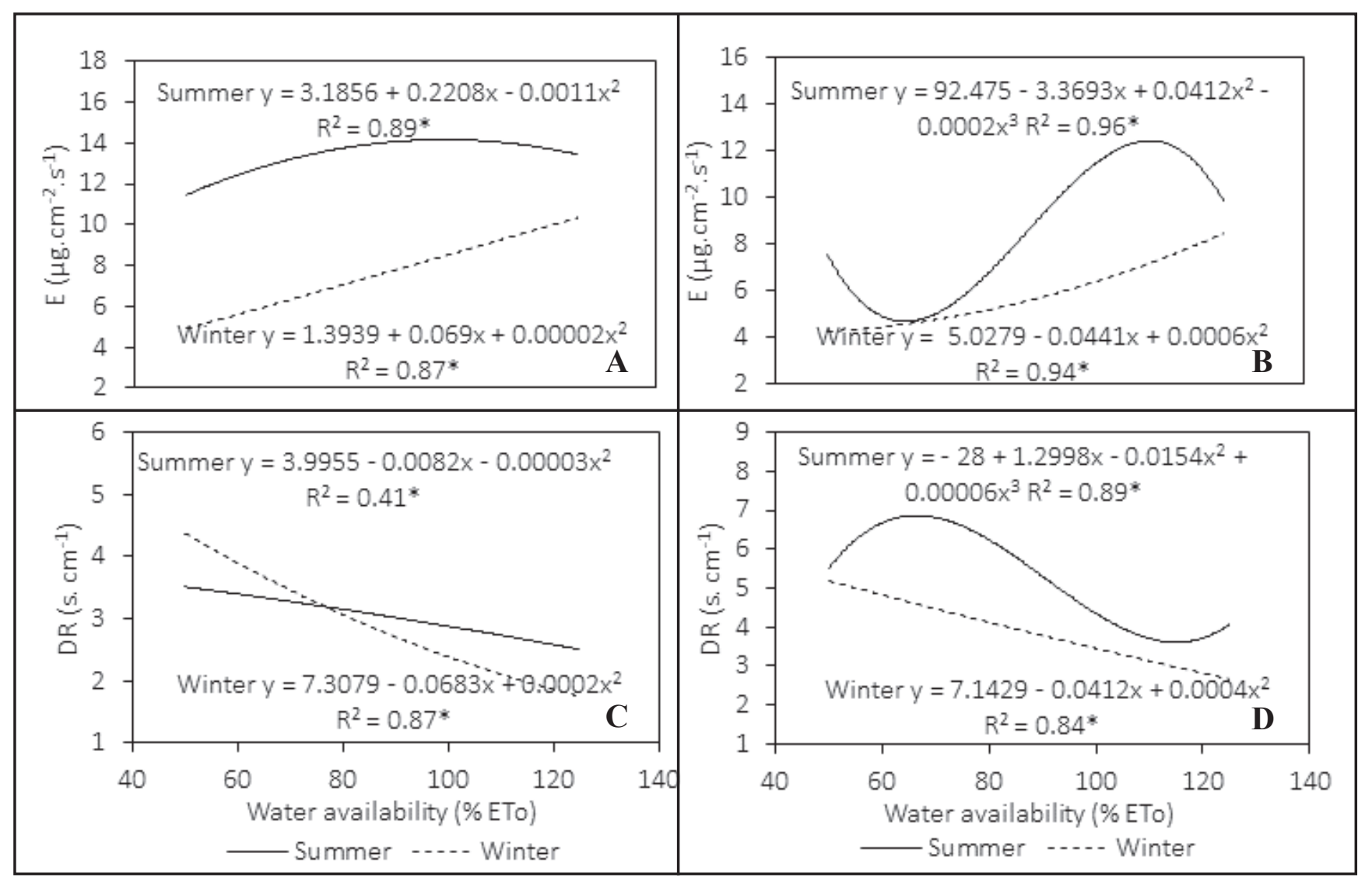

Figure 3. Transpiration and vapor diffusion resistance evaluated on the abaxial (A and B) and adaxial (C and D) faces of cidró leaves related to water availability (\%ETo) based on the reference evapotranspiration ETo (mm/day). Frederico Westphalen, UFSM, 2012.

to conclude that physiological response of cidró plants was influenced by water replacement levels, in a different way according to the seasons of the year. Summer was responsible for the higher photosynthetically active radiation, leaf temperature, transpiration and stomatal vapor diffusion resistance values. The reduction in water availability promoted an increase in values of stomatal resistance to vapor flow, reducing leaf transpiration rate. Photosynthetically active radiation, leaf temperature and transpiration showed higher values on abaxial face of the studied species.

\section{ACKNOWLEDGEMENTS}

The authors thank to Conselho Nacional de Desenvolvimento Científico e Tecnológico (CNPq) (National Council for Scientific and Technological Development) and Coordenação de Aperfeiçoamento de Pessoal de Nível Superior (CAPES) for financial support and for the Master scholarship granted to the author Luciano Schwerz.

\section{REFERENCES}

ALLEN, RG; PEREIRA, LS; RAES, D; SMITH, M. 1998. Crop evapotranspiration: guidelines for computing crop water requirements. Rome, FAO. 300p.

BATISTA, LA; GUIMARÃES, RJ; PEREIRA, FJ; CARVALHO, GR; CASTRO, EM. 2010. Anatomia foliar e potencial hídrico na tolerância de cultivares de café ao estresse hídrico. Revista Ciência Agronômica 41: 475-481.

BRANT, RS; PINTO, JEB; BERTOLUCCI, SKV; ALBUQUERQUE, CJB. 2008. Teor do óleo essencial de cidrão (Aloysia triphylla (L'Hérit) Britton Verbenaceae) em função da variação sazonal. Revista Brasileira de Plantas Medicinais 10: 83-88.

BRANT, RS; PINTO, JEB; BERTOLUCCI, SKV; ALBUQUERQUE, CJB. 2010. Produção de biomassa e teor do óleo essencial de cidrão em função da adubação orgânica. Horticultura Brasileira 28: 111-114.

CALZADA, F; ARISTA, R; PÉREZ, H. 2010. Effect of plants used in Mexico to treat gastrointestinal disorders on charcoal-gum acacia-induced hyperperistalsis in rats. Journal of Ethnopharmacology 128: 49-51.

CARON, BO; PERRANDO, ER; SCHMIDT, D; MANFRON, PA; BEHLING, A; ELLI, EF; ELOY, E. 2014. Relações fisiológicas em mudas de pata-de-vaca (Bauhinia forficata Link). Revista Brasileira de Plantas Medicinais 16: 196-201.

CASAROLI, D; LIER, QJV; IRIGOYEN, AI; SIMON, J; SCARPARE, FV. 2008. Estimativa da taxa de transpiração do feijoeiro a partir de medidas de porometria, em diferentes camadas do dossel. Revista Brasileira de Agrometeorologia 16: 149-153.

CIAVATTA, SF. 2010. Fertirrigação na produção e qualidade de mudas de Eucalyptus spp. nos periodos de inverno e verão. Botucatu: Unesp. 82p. (Dissertação mestrado).

COSTA, GF; MARENCO, RA. 2007. Fotossíntese, condutância estomática e potencial hídrico foliar em árvores jovens de andiroba (Carapa guianensis). Acta Amazonica 37: 229-234.

DALMAGO, GA; HELDWEIN, AB; NIED, AH; GRIMM, EL; PIVETTA, CR. 2006. Evapotranspiração máxima da cultura do pimentão em estufa plástica em função da radiação solar, da temperatura, da umidade relativa e do déficit de saturação do ar. Ciência Rural 36: 785-792.

ELLI, EF; CANTARELLI, EB; CARON, BO; MONTEIRO, GC; PAVAN, MA; PEDRASSANI, M; ELOY, E. 2013. Osmocote no desenvolvimento e comportamento 
fisiológico de mudas de pitangueira. Comunicata Scientiae 4: 377-384.

EMBRAPA - Empresa Brasileira de Pesquisa Agropecuária. 2006. Sistema Brasileiro de Classificação de Solos. Rio de Janeiro: EMBRAPA-SPI. 412p.

GUIMARÃES, CM; STONE, LF; BRUNINI, O. 2006. Adaptação do feijoeiro comum (Phaseolus vulgaris L.) à seca. Revista Brasileira de Engenharia Agricola e Ambiental 10: 70-75.

MARTINEZ, CA; MORENO, U. 1992. Expresiones fisiologicas de resistencia a la sequia en dos variedades de papa sometidas a estres hidrico en condiciones de campo. Revista Brasileira de Fisiologia Vegetal 4: 33-38.

MARTINS, MBG; FLORIANO, PR. 2002. Anatomia foliar de Illicium verum Hook (anis), com ênfase nas estruturas secretoras. Revista Hispeci \& Lema 6: 39-43.

MENDES, RMS; TÁVORA, FJAF; PINHO, JLN; PITOMBEIRA, JB. 2007. Relações fonte-dreno em feijão-de-corda submetido à deficiência hídrica. Ciência Agronômica 38: 95-103.

MERCADO, LM; BELLOUIN, N; SITCH, S; BOUCHER, O; HUNTINGFORD, C; WILD, M; COX, PM. 2009. Impact of changes in diffuse radiation on the global land carbon sink. Nature 458: 1014-1017.

NASCIMENTO, SP; BASTOS, EA; ARAÚJO, ECE; FREIRE FILHO, FR; SILVA, EM. 2011. Tolerância ao déficit hídrico em genótipos de feijão-caupi. Revista Brasileira de Engenharia Agrícola e Ambiental 15: 174-177.

NOGUEIRA, RJMC; MORAES, JAPV; BURITY, HA. 2000. Curso diário e sazonal das trocas gasosas e do potencial hídrico foliar em aceroleiras. Pesquisa Agropecuária Brasileira 35: 1331-1342.

NOGUEIRA, RJMC; MORAES, JAPV; BURITY, HA; NETO, EB. 2001. Alterações na resistência à difusão de vapor das folhas e relações hídricas em aceroleiras submetidas a déficit de água. Revista Brasileira de Fisiologia Vegetal 13: 75-87.

OLIVEIRA，AD; FERNANDES，EJ; RODRIGUES, TJD. 2005. Condutância estomática como indicador de estresse hídrico em feijão. Engenharia Agrícola 25: 86-95.

PAULUS, D; VALMORBIDA, R; TOFFOLI, E; NAVA, GA. 2013. Teor e composição química de óleo essencial de cidró em função da sazonalidade e horário de colheita. Horticultura Brasileira 31: 203-209.

PIVETTA, CR; HELDWEIN, AB; MALDANER, IC; RADONS, SZ; TAZZO, IF; LUCAS, DD.
2010. Evapotranspiração máxima do pimentão cultivado em estufa plástica em função de variáveis fenométricas e meteorológicas. Revista Brasileira de Engenharia Agrícola e Ambiental 14: 768-775.

RODRIGUES-DAS-DORES, RG; CASALI, VWD. 2007. Plantas Medicinais e Aromáticas: controle de qualidade de fitoterápicos. Ponte Nova: D\&M. 160p.

SAS learning edition. 2003. Getting started with the SAS Learning Edition. Cary. 200p.

SCHIPPERS, P; STERCK, F; VLAM, M; ZUIDEMA, PA. 2015. Tree growth variation in the tropical forest: understanding effects of temperature, rainfall and $\mathrm{CO} 2$. Global Change Biology 21: 2749-2761.

SILVA, F; CASALI, VWD. 2000. Plantas medicinais e aromáticas: Pós colheita e óleos essenciais. Viçosa: Arte e Livro. 135p.

TAIZ, L; ZEIGER, E. 2013. Fisiologia Vegetal. Porto Alegre: Artmed. 917p.

VAN DER SLEEN, P; GROENENDIJK, P; VLAM, M; ANTEN, NPR; BOOM, A; BONGERS, F; PONS, TL; TERBURG, G; ZUIDEMA, PA. 2014. No growth stimulation of tropical trees by 150 years of $\mathrm{CO} 2$ fertilization but water-use efficiency increased. Nature Geoscience 8: 24-28. 